\title{
Detection of Extended Spectrum Beta Lactamases Among Clinical Isolates of Pseudomonas aeruginosa
}

\author{
Shree Dhotre', Vilas Jahagirdar², Basavraj Nagoba ${ }^{3}$
}

\begin{abstract}
${ }^{1}$ Assistant Professor Department of Microbiology, M.M. Patel Public Charitable Trust's, Ashwini Medical College \& Hospital, Kumbhari-413006, Solapur, Maharashtra, India.
\end{abstract}

${ }^{2}$ Formerly Dean \& Professor of Microbiology Govt. Medical College, Miraj, Maharashtra, India.

${ }^{3}$ Assistant Dean (R\&D) \& Professor of Microbiology Maharashtra Institute of Medical Sciences \& Research, Latur-413 531, Maharashtra, India.

Eur J Basic Med Sci 2015;5(3): 45-50

Received: 19-01-2016

Accepted: 25-05-2016

Correspondence (Yazıșma Adresi):

Dr. B. S. Nagoba

Assistant Dean, Research \& Development, Maharashtra Institute of Medical Sciences \& Research, Latur-413 531,M.S., India. Email:dr_bsnagoba@yahoo.com, bsnagoba@gmail.com

Office Telephone: +912382227587

Mobile No.+919423075786/+917588237531

\begin{abstract}
Infections caused by Pseudomonas aeruginosa are tough to treat as the majority of these isolates exhibit varying degrees of beta-lactamase mediated resistance. These enzymes are capable of hydrolyzing broad spectrum cephalosporins and monobactams but inactive against cephamycins and imipenem. Resistance to broad-spectrum beta lactams, mediated by extended-spectrum beta lactamases (ESBLs), is an increasing problem worldwide. In addition, ESBL producing organism's exhibit coresistance to several other classes of antibiotics resulting in limitation of therapeutic option. This resistance poses problems for testing and reporting. Increased prevalence of ESBLs among clinical isolates creates a great need for laboratory testing methods that will accurately identify their presence. Thus the present study was designed to investigate the prevalence of extended-spectrum beta lactamases (ESBLs) in clinical isolates of $P$. aeruginosa. A total of 150 clinical isolates of $P$. aeruginosa were isolated from various clinical samples were tested for antimicrobial susceptibility by Kirby-Baeur disk diffusion method. 75 isolates showing a zone diameter less than $18 \mathrm{~mm}$ to Cefoxitin (screen positive) were tested for the presence of extended spectrum beta-lactamase (ESBL) by disk approximation method using cefoxitin inducer and cefotaxime indicator method as per Clinical and Laboratory Standards Institute (CLSI) guidelines. Antibiogram of P. aeruginosa isolates revealed that, highest resistance was observed to gentamycin (73.67\%), followed by ceftazidime (70.67\%), amikacin $(63.33 \%)$, ciprofloxacin (52.67\%) in that order of frequencies. Maximum susceptibility was observed to carbenicillin (72\%). Multiple drug resistance was common phenomenon observed, in more than 50\% of strains. 78 (52\%) isolates showed resistance to six or more antibiotics. $65.33 \%$ of $P$. aeruginosa strains showed extended spectrum beta-lactamase production in $(70.73 \%)$ isolates from pus followed by urine (62.5\%). The study emphasizes the high prevalence of multidrug resistant $P$. aeruginosa producing extended spectrum beta-lactamase using a simple disk approximation method. Thus proper antibiotic policy and measures to restrict the indiscriminative use of cephalosporins and carbapenems should be taken to minimize the emergence of this multiple beta-lactamase producing pathogens.
\end{abstract}

Key Words: Extended spectrum beta-lactamase, P. aeruginosa, resistance.

Abbreviations: Amikacin (AMK), Ciprofloxacin (CIP), Cefotaxime (CTX), Ceftazidime (CAZ), Norfloxacin (NOR), Lomefloxacin (LOM), Gentamycin (GEN), Carbenicillin (CAR) 
Pseudomonas aeruginosa'nın Klinik izolatları Arasında Geniş Spektrumlu Beta Laktamazların tespiti

\section{ÖZET}

Pseudomonas aeruginosa'nın neden olduğu enfeksiyonları, değișik derecelerde beta-laktamaz aracılı direnç gösteren bu izolatlara bağlı olarak çoğunlukla tedavi etmek zordur. Bu enzimler geniş spektrumlu sefalosporinler ve monobaktamları hidrolize edebilirler fakat sefamisinlere ve imipeneme karșl inaktiftirler. Geniș spektrumlu beta laktamazlar (ESBL) aracılığı ile geniş spektrumlu beta laktamlara direnç, tüm dünyada giderek artan bir sorundur. Buna ek olarak, antibiyotiklerin diğer birkaçına karșı birlikte direnç gösteren ESBL üreten organizmaların varlığı tedavi seçeneğinin sınırlı olması ile sonuçlanır. Bu direnç test ve raporlama için sorun teșkil etmektedir. Klinik izolatlar arasında ESBL sıklığının artışı, onların varlığını tam olarak tespit edecek laboratuvar test yöntemleri için büyük bir ihtiyaç doğurur. Bundan dolayı, mevcut çalıșmada P. aeruginosa'nın klinik izolatlarında geniş spektrumlu beta laktamazların (ESBL) prevalansının araștırılması planlandı. Çeșitli klinik örneklerden izole edilen, P. aeruginosa'nın toplam 150 klinik izolatı Kirby-Bauer disk difüzyon yöntemi ile antimikrobiyal duyarlılık açısından test edildi. Klinik ve Laboratuar Standartları Enstitüsü (CLSI) kurallarına uygun olarak sefoksitin indükleyici ve sefotaksim gösterge yöntemini kullanarak disk yaklașım metodu ile geniș spektrumlu beta-laktamaz (ESBL) varlığı açısından sefoksitin 18 mm'den daha az diameter zon gösteren (tarama pozitif) 75 izolat test edildi. P. aeruginosa izolatları'nın antibiyogramı, en yüksek direncin gentamisin (\%73.67)'e, bunu takiben, sirasiyla seftazidim (\%70.67), amikasin (\%63.33), siprofloksasin (\%52.67)'e olduğu gözlenmiștir. En fazla duyarlılık karbenisilin (\%72)'e gözlenmiștir. Çoklu ilaç direnci, sușların \%50'den daha fazlasında yaygın bir olgu olarak gözlenmiștir. 78 (\%52) izolat, altı veya daha fazla antibiyotiğe karșı direnç göstermiștir. P. aeruginosa suşlarının \%65.33'ü geniș spektrumlu B laktamaz üretimini, cerahatttan (\%70.73) bunu takiben idrardan (\%62.5) elde edilen izolatlarda gösterdi. Bu çalıșma basit bir disk yaklaşım yöntemi kullanılarak geniş spektrumlu beta-laktamaz üreten $P$. aeruginosa'nın çoklu ilaca direncinin yüksek prevalansını vurgulamaktadır. Bu yüzden sefalosporin ve karbapenemlerin gelișigüzel kullanımını kısıtlayacak uygun antibiyotik politikası belirlenmeli ve çoklu beta-laktamaz üreten patojenlerin ortaya çıkmasını en aza indirmek için önlemler alınmalıdır.

Anahtar Kelimeler: Geniș spektrumlu beta-laktamazlar, P. aeruginosa, direnç.

\section{INTRODUCTION}

Resistant bacteria are emerging world wide as a threat to the favourable outcome of common infections in community and hospital settings. The main mechanism of resistance to beta-lactam antibiotics among gram-negative isolates is beta-lactamase biosynthesis. Beta-Lactamases inactivate penicillins and cephalosporins by hydrolyzing the amide bond of the beta-lactam ring. The numerous beta-lactamase sequences allow them to be divided into four molecular classes according to their amino acid content, designated A to D (1). Resistance to extended-spectrum cephalosporins is usually observed in members of the family Enterobacteriaceae, with extended-spectrum variants from class A beta-lactamases TEM-1, TEM-2, and SHV-1 (2). These plasmid mediated extended-spectrum enzymes were first reported in Klebsiella pneumoniae and later in almost all other Enterobacteriaceae. These variants differ from their parent enzymes by only a few amino acid positions (3) within their catalytic sites (3) but can hydrolyze broad-spectrum beta-lactam antibiotics such as penicillins and cephalosporins, including oxyimino beta lactams (cefotaxime, ceftazidime, and aztreonam). However, they do not hydrolyze cephamycins (cefoxitin) or carbapenems (imipenem or meropenem) (3).

Table 1. Correlation of clinical history with source of isolation.

\begin{tabular}{|c|c|c|}
\hline Source & Diagnosis & No. of cases \\
\hline $\begin{array}{l}\text { Pus } \\
n=93(62 \%)\end{array}$ & $\begin{array}{l}\text { Burn wound } \\
\text { Acute otitis media } \\
\text { Foot ulcer } \\
\text { Chronic Osteomyelitis } \\
\text { Cellulitis } \\
\text { Abscess } \\
\text { Empyema }\end{array}$ & $\begin{array}{l}54 \\
09 \\
17 \\
01 \\
04 \\
06 \\
02\end{array}$ \\
\hline $\begin{array}{l}\text { Urine } \\
n=24(16 \%)\end{array}$ & UTI & 24 \\
\hline $\begin{array}{l}\text { Sputum } \\
n=12(8 \%)\end{array}$ & $\begin{array}{l}\text { Pneumonia } \\
\text { Bronchitis }\end{array}$ & $\begin{array}{l}04 \\
08\end{array}$ \\
\hline $\begin{array}{l}\text { Conjunctival Swab. } \\
n=12(12 \%)\end{array}$ & $\begin{array}{l}\text { Immat/mat/Traumatic } \\
\text { cataract } \\
\text { Conjunctivitis } \\
\text { Corneal abscess }\end{array}$ & $\begin{array}{l}10 \\
01 \\
01\end{array}$ \\
\hline $\begin{array}{l}\text { Stool } \\
n=3(2 \%)\end{array}$ & $\begin{array}{l}\text { PEM } \\
\text { Intestinal Obstruction }\end{array}$ & $\begin{array}{l}02 \\
01\end{array}$ \\
\hline $\begin{array}{l}\text { Blood } \\
n=2(1.33 \%)\end{array}$ & Fever & 02 \\
\hline $\begin{array}{l}\text { CSF } \\
n=1(0.66 \%)\end{array}$ & Meningitis & 01 \\
\hline $\begin{array}{l}\text { Intra Costal drain } \\
n=1(0.66 \%)\end{array}$ & Hydropneumothorax & 01 \\
\hline Total & & 150 \\
\hline
\end{tabular}


Table 2. Antimicrobial susceptibility pattern of P.aeruginosa $(n=150)$.

\begin{tabular}{lllll}
\hline Antibiotics & Disk Conc. & Symbols & \multicolumn{2}{l}{ Susceptibility Pattern } \\
& $\mu \mathrm{g}$ & & Resistant & Susceptible \\
\hline Gentamycin & 10 & GEN & $118(73.67 \%)$ & $32(21.33 \%)$ \\
Norfloxacin & 10 & NOR & $71(47.33 \%)$ & $79(52.67 \%)$ \\
Ciprofloxacin & 5 & CIP & $79(52.67 \%)$ & $71(47.33 \%)$ \\
Amikacin & 30 & AMK & $95(63.33 \%)$ & $55(36.67 \%)$ \\
Cephotaxime & 30 & CTX & $48(32 \%)$ & $102(68 \%)$ \\
Carbenicillin & 100 & CAR & $42(28 \%)$ & $108(72 \%)$ \\
Ceftazidime & 30 & CAZ & $106(70.67 \%)$ & $44(29.33 \%)$ \\
Lomefloxacin & 10 & LOM & $73(48.67 \%)$ & $77(51.33 \%)$ \\
\hline
\end{tabular}

Amikacin (AMK), Ciprofloxacin (CIP), Cefotaxime (CTX), Ceftazidime (CAZ), Norfloxacin (NOR), Lomefloxacin (LOM), Gentamycin (GEN),

Carbenicillin (CAR)

Extended spectrum beta-lactams are routinely added in empirical antibiotic regimens for the treatment of Gramnegative infections. The evolution of extended-spectrum beta-lactamase (ESBL)-producing bacteria present a grave risk to the continued use of this family of antibiotics (4).

The current automated susceptibility test methods do not reliably detect ESBL production. Other techniques such as polymerase chain reaction (PCR), PCR-restriction fragment length polymorphism and direct nucleotide sequencing, which demonstrate ESBL production, are of variable sensitivity and may be time consuming, expensive or technically difficult to perform. There is a need for an easy, rapid and reproducible method for the detection of ESBLs, suitable for use in the routine diagnostic laboratory. Additionally, if the method could utilize the same methodology as antimicrobial susceptibility testing, the use of extra one or two discs only would enable all clinical isolates to be screened during routine susceptibility testing (4).

Hence, the present study was designed to investigate the prevalence of extended spectrum beta-lactamase enzymes in clinical isolates of $P$. aeruginosa using a simple disk approximation method, which could be easily used in the routine diagnostic laboratory.

\section{MATERIAL AND METHOD}

This study is a prospective study, which was approved by the institutional ethical committee. The study included a total of 150 consecutive non-duplicate isolates of $P$. ae- ruginosa obtained from different clinical specimens from patients who were admitted in different wards as well as from those who attended the outpatient departments of our tertiary care hospital.

All the isolates of $P$. aeruginosa which showed susceptibility to cefoxitin were evaluated for ESBL production by using the phenotypic disk approximation confirmatory test $(5,6)$. The disk approximation test was used for detection of ESBL in all the isolates of $P$. aeruginosa. A test isolate (with a turbidity equivalent to that of $0.5 \mathrm{McF}$ arland standards) was spread over a Mueller Hinton agar (Hi-Media)

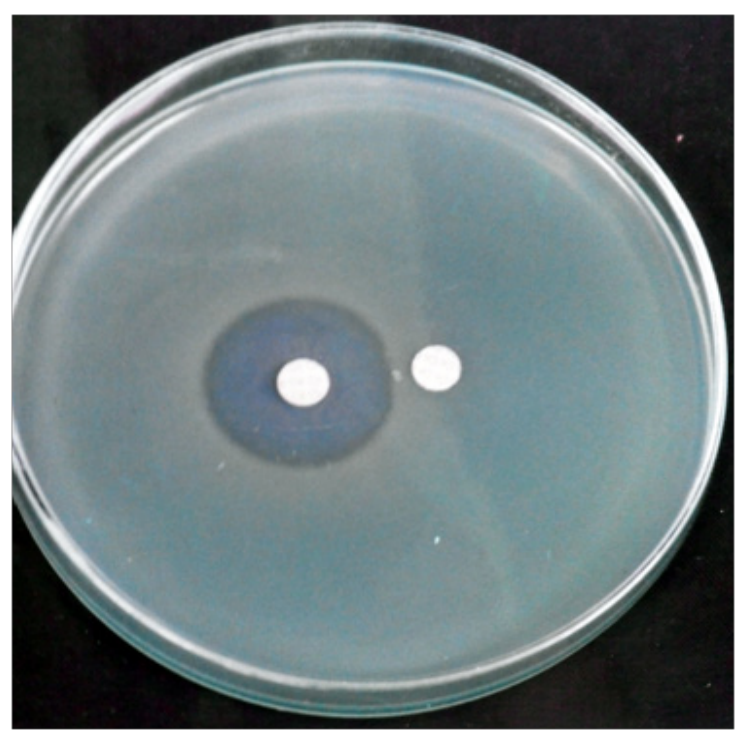

Figure 1. Positive ESBL test (Disk Approximation Method) showing no zone of inhibition around cefoxitin and flattering of inhibition zone around cefotaxime disk. 
Table 3. R-pattern observed among P.aeruginosa strains.

\begin{tabular}{llll}
\hline No. of Strains & Resistance & R-pattern & Resistance (\%) \\
\hline P.aeruginosa & 08 & GEN, NOR, CIP, AMK, CTX, CAR, CAZ, LOM & $33(22 \%)$ \\
$(141)$ & 07 & GEN, NOR, CIP, AMK, CAR, CAZ, LOM & $20(13.33 \%)$ \\
& 07 & GEN, NOR, CIP, AMK, CTX, CAZ, LOM & $08(5.33 \%)$ \\
& 06 & GEN, NOR, CIP, CTX, CAZ, LOM & $17(11.33 \%)$ \\
& 05 & GEN, NOR, CIP, CAZ, LOM & $16(10.67 \%)$ \\
& 04 & GMK, CTX, CAR, CAZ & $04(2.67 \%)$ \\
& 04 & GEN, NOR, CIP, CAZ & $04(2.67 \%)$ \\
& 03 & GEN, CTX, CAZ & $07(4.67 \%)$ \\
& 03 & GEN, CAZ, LOM & $05(3.33 \%)$ \\
& 02 & CTX, CAZ & $06(10.67 \%)$ \\
& GEN CAZ & GEN, CTX & $05(3.33 \%)$ \\
& 02 & GEN , LOM & $04(2.67 \%)$ \\
& 02 & GEN & $04(2.67 \%)$ \\
& 01 & CAZ & $04(2.67 \%)$ \\
& 01 & G & $04(2.67 \%)$ \\
\hline
\end{tabular}

Amikacin (AMK), Ciprofloxacin (CIP), Cefotaxime (CTX), Ceftazidime(CAZ), Norfloxacin (NOR), Lomefloxacin (LOM), Gentamycin (GEN),

Carbenicillin (CAR)

plate. Cefotaxime $(30 \mu \mathrm{g})$ and cefoxitin $(30 \mu \mathrm{g})$ (Hi-Media Mumbai) disks were placed $20 \mathrm{~mm}$ apart from centre to centre. Isolates showing blunting of the cefotaxime zone of inhibition adjacent to the cefoxitin disk were screened as positive for $\operatorname{ESBL}(5,6)$ (Figure 1).

Antimicrobial susceptibility was performed by the KirbyBaeur disk diffusion method for various antibiotics, namely: Amikacin $(30 \mu \mathrm{g})$, Ciprofloxacin $(5 \mu \mathrm{g})$, Cefotaxime

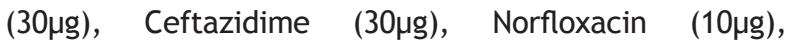
Lomefloxacin $(10 \mu \mathrm{g})$, Gentamycin $(10 \mu \mathrm{g})$, Carbenicillin $(100 \mu \mathrm{g})(\mathrm{Hi}-$ Media Mumbai). The results were interpreted according to the standard table provided along with the disk (6).

\section{RESULTS}

Table 1 shows the correlation of clinical history and source of isolation. In the present study majority of $P$. aeruginosa strains were isolated in pus samples 93 (62\%) followed by urine 24 (16\%), conjunctival swab and sputum were 12 (8\%) each. The maximum numbers of isolates were from burn wounds (36\%) and foot ulcer (11.3\%).

The antibiogram of $150 P$. aeruginosa isolates is shown in table 2. Among the antibiotics used resistance to GEN (73.67\%), CAZ (70.67\%) was most frequently observed, followed by AMK (63.33\%) and CIP (52.67\%). Maximum susceptibility was observed with CAR i.e. (72\%).
Among the 150 P.aeruginosa isolates 141 were resistant to one or more antibiotics (Table 3). Most of P.aeruginosa strains $33(22 \%)$ were resistant to all 8 antibiotics, followed by $28(18.67 \%)$ strains resistant to 7 antibiotics (GEN, NOR, CIP, AMK, CAR, CAZ, LOM) which was the most frequent resistance pattern. Majority of the $P$. aeruginosa isolates $94(62.67 \%)$ were resistant to 5 or more antibiotics. 9 strains were found to be sensitive to all the antibiotics tested.

Table 4 summarises the distribution of extended spectrum beta lactamase activity of $P$. aeruginosa isolates from different clinical source. 49 (65.33\%) P. aeruginosa isolates

Table 4. ESBL positivity according to their clinical source.

\begin{tabular}{llll}
\hline $\begin{array}{l}\text { Clinical } \\
\text { Source }\end{array}$ & Total & ESBL Positive & ESBL Negative \\
\hline PUS & 41 & $29(70.73 \%)$ & $12(29.27 \%)$ \\
Urine & 16 & $10(62.5 \%)$ & $06(37.5 \%)$ \\
Conjunctival & 07 & $04(57.14 \%)$ & $03(42.86 \%)$ \\
$\begin{array}{l}\text { Swab } \\
\text { Sputum }\end{array}$ & 06 & $04(66.67 \%)$ & $02(33.33 \%)$ \\
$\begin{array}{l}\text { Stool } \\
\text { CSF }\end{array}$ & 02 & --- & $02(100 \%)$ \\
Intra costal & 01 & --- & $01(100 \%)$ \\
drain & 01 & $1(100 \%)$ & -- \\
Blood & 01 & $1(100 \%)$ & --- \\
Total & 75 & $49(65.33 \%)$ & $26(34.67 \%)$ \\
\hline
\end{tabular}


Table 5. R-pattern and ESBL activity.

\begin{tabular}{lllll}
\hline Strains & Resistance & R-pattern & No. of strains & ESBL Positive \\
\hline 75 & 07 & GEN NOR, CIP, AMK, CAR, CAZ, LOM & 20 & $+(20)$ \\
P.aeruginosa & 06 & GEN NOR, CIP, CAR, CAZ, LOM & 17 & $+(16)$ \\
& 05 & GEN, NOR, CIP, CAZ, LOM & 16 & $+(13)$ \\
& 04 & GEN, CIP, CAZ, LOM & 05 & $\cdots$ \\
& 03 & GEN, CIP, CAZ & 05 & $\cdots$ \\
& 02 & GEN, LOM & 04 & $\cdots$ \\
& 01 & GEN & 04 & $\cdots$ \\
Total & 01 & CAZ & 04 & $-\cdots$ \\
\hline
\end{tabular}

Amikacin (AMK), Ciprofloxacin (CIP), Cefotaxime (CTX), Ceftazidime (CAZ), Norfloxacin (NOR), Lomefloxacin (LOM), Gentamycin (GEN), Carbenicillin (CAR)

produced ESBL. Majority of ESBL producing $P$. aeruginosa strains $29(70.73 \%)$ were isolated from pus, followed by sputum (66.67\%).

Table 5 summarises the distribution of extended spectrum beta lactamase activity in $P$. aeruginosa strains. Of the 49 (65.33\%) ESBL positive strains 20 (100\%) were resistant to seven antibiotics followed by 16 (94.12\%) strains resistant to 6 antibiotics. All the ESBL positive strains were resistant to 5 or more antibiotics.

\section{DISCUSSION}

Production of ESBLs by $P$. aeruginosa has tremendous therapeutic consequences and poses a significant clinical challenge if it remains undetected, early identification of the infections due to these organisms is necessary as the appropriate treatment might reduce the spread of these resistant strains as well as reduce the mortality in hospitalized patients. This emphasizes the need for the detection of isolates that produce these enzymes to avoid therapeutic failures and nosocomial outbreaks. Since there is no standard guideline for detection of most of these beta-lactamase enzymes in $P$. aeruginosa, the comparison between studies becomes difficult as the patient population in particular centres and the methods of study differ. In comparison to the earlier studies conducted at other centres, we found a very high prevalence of these beta-lactamase producing P. aeruginosa (65.33\%) $(6,7)$. The increase in ESBL producing isolates may be indicative of the ominous trend of more and more iso- lates acquiring resistance mechanisms rendering all the available antimicrobial ineffective. Our study reported very high incidence of ESBL among $P$. aeruginosa, which contrasts an earlier study which showed 3.3\% and $22.22 \%$ of ESBL production $(6,7)$. The only beta-lactam active against ESBL producers are carbapenems; however, recently resistance to carbapenems has been increasing, In our study carbenicillin was found to be the most effective drug, showing maximum susceptibility of $72 \%$, which is in agreement with earlier studies $(6,8,9)$.

Although molecular methods appear sensitive detection of ESBL-producing strains in the clinical laboratory (10, 11) they are expensive, time consuming, and require specialized equipment and expertise. In this study we could reliably screen out the extended spectrum beta lactamase producing $P$. aeruginosa by using the disc approximation method which is in accordance with earlier studies $(6,7,10)$. The disk approximation method affords a reliable option for ESBL detection for all Gram-negative bacteria to be screened in the routine diagnostic laboratory.

The present study emphasizes the high prevalence of multidrug resistant Pseudomonas aeruginosa producing extended spectrum beta-lactamase enzyme prevailing in present clinical settings. To combat these problems, epidemiological studies should be undertaken in hospital settings to monitor the source of infection. Early detection of these extended spectrum beta-lactamase producing isolates in a routine laboratory could help to avoid treatment failure, as often the isolates producing this enzyme show a susceptible phenotype in routine susceptibility 
testing. Furthermore, strict antibiotic policies and measures to limit the indiscriminative use of cephalosporins and carbapenems in the hospital environment should be undertaken to minimize the emergence of this multiple beta-lactamase producing pathogen whose spread would leave no other option to treat Gram-negative nosocomial infections.

Conflict of Interest: None to Declare

Source of funding: No funding

\section{REFERENCES}

1. Ambler, R. P. The structure of B-lactamases. Philos Trans $R$ Soc Lond 1980; B 289:321-331.

2. Philippon, A., G. Arlet, and P. H. Lagrange. Origin and impact of plasmid-mediated extended-spectrum betalactamases. Eur J Clin Microbiol Infect Dis 1994;13(Suppl. 1):17-29.

3. Philippon LN, Naas T, Bouthors A-typhaine, Barakett $V$, Nordmann P, Be A. OXA-18, a Class D Clavulanic Acid-Inhibited Extended-Spectrum B-Lactamase from Pseudomonas aeruginosa. Antimicrob Agents Chemother 1997;41(10):2188-95.

4. Zali FHM, Chanawong A, Kerr KG, Birkenhead D, Hawkey PM. JAC Detection of extended-spectrum B-lactamases in members of the family Enterobacteriaceae: comparison of the MAST DD test, the double disc and the Etest ESBL. J Antimicrobial Chemotherapy 2000;45:881-5.
5. Chaudhary U, Aggarwal R. Extended spectrum B-lactamases ( ESBL ) - An emerging threat to clinical therapeutics. Ind $J$ Med Microbiol 2004;22(2):75-80.

6. Revathi $G$, Singh S, Simrita S. Detection of expanded spectrum cephalosporin resistance due to inducible lactamases in hospital isolates. Ind J Med Microbiol 1997;15:113-115.

7. Peshattiwar PD, Peerapur BV. ESBL and MBL Mediated Resistance in Pseudomonas aeruginosa: An Emerging Threat to Clinical Therapeutics. J Clin Diagn Res 2011; 5(8): 1552-4.

8. Aggarwal R, Chaudhary U, Bala K. Detection of extended spectrum beta lactamase in Pseudomonas aeruginosa. Ind J Pathol Microbiol 2008;51: 222-224.

9. Hemlatha V, Sekar U, Kamat V. Prevalence of metallo beta lactamase producing Pseudomonas aeruginosa in hospitalized patients. Ind J Med Res 2005;122: 148-152.

10. Giriyapur RS, Nandihal NW, Krishna BVS, PatilAB, Chandrasekhar M R. Comparison of Disc Diffusion Methods for the Detection of Extended-Spectrum Beta LactamaseProducing Enterobacteriaceae. J Lab Physicians 2011;3(1): 33-36.

11. Polsfuss S, Bloemberg GV, Giger J, Meyer V, Hombach M. Comparison of European Committee on Antimicrobial Susceptibility Testing (EUCAST) and CLSI screening parameters for the detection of extended-spectrum B-lactamase production in clinical Enterobacteriaceae isolates. J Antimicrob Chemother 2012;67(1):159-66. 